\title{
Hydrogeochemistry of Groundwater from Different Aquifer in Dimbhe Command Area of Ghod River, Maharashtra India
}

\author{
Geeta Pillai, Iftekhar A. Khan \\ Department of Geology \& Petroleum Technology, N. Wadia College, Pune, India \\ Email: geetapillai54@gmail.com
}

How to cite this paper: Pillai, G. and Khan, I.A. (2017) Hydrogeochemistry of Groundwater from Different Aquifer in Dimbhe Command Area of Ghod River, Maharashtra India. Journal of Water Resource and Protection, 9, 656-662.

https://doi.org/10.4236/jwarp.2017.96044

Received: January 26, 2017

Accepted: May 24, 2017

Published: May 27, 2017

Copyright ( 92017 by authors and Scientific Research Publishing Inc. This work is licensed under the Creative Commons Attribution International License (CC BY 4.0).

http://creativecommons.org/licenses/by/4.0/

\begin{abstract}
The groundwater geochemistry of Dimbhe command area of Ghod River basin was evaluated based on major ions characteristic to decide its suitability for drinking, domestic use, and irrigation. Groundwater samples from different depth (shallow and deep) aquifer were collected and investigated for $\mathrm{pH}$, electrical conductivity (EC), total dissolved solid (TDS), $\mathrm{Ca}, \mathrm{Mg}, \mathrm{Na}, \mathrm{K}, \mathrm{Cl}$, $\mathrm{SO}_{4}, \mathrm{CO}_{3}, \mathrm{HCO}_{3}, \mathrm{NO}_{3}, \mathrm{Fe}$, and $\mathrm{Mn}$. The results show that the shallow groundwater is dominated by $\mathrm{Ca}-\mathrm{HCO}_{3}$ and $\mathrm{Na}-\mathrm{HCO}_{3}$ and deep aquifer by $\mathrm{Na}-\mathrm{HCO}_{3}$ water facies. The sodium adsorption ratio (SAR) and salinity hazard indicate that the groundwater from the shallow and deep aquifer is suitable for irrigation purposes, and part of the intermediate aquifer is not suitable for crop irrigation. Groundwater from the shallow and deep aquifer is regarded as fresh water and suitable for drinking, domestic and agricultural irrigation use.
\end{abstract}

\section{Keywords}

Dimbhe Command Area of Ghod River, Hydrochemical Facies, Sodium Adsorption Ratio (SAR)

\section{Introduction}

The biosphere's main available freshwater and essential resource is groundwater. The world depends on groundwater for intake water supply, green growth, and industrialized purposes as well as for worldwide foodstuff safety. Nearly world's thirty-three percent inhabitants depend on subsurface water for drinking purpose [1]. The geochemistry of water is depends on rock type of an area, also the amount of chemical weathering of rock and man induced factor like land-use affect the chemistry of groundwater [2]. The combination of productive soil, 
moderately undulating topography with the superficial water level and widespread of the aquifer with plentiful and easily accessible of water make the groundwater the main source of water among the residents in the Dimbhe command area of Ghod river basin. About 75\% populations living in the Ghod river basin are dependent on surface and subsurface water for domestic, farming and industrial activities. The subsurface water requires negligible treatment and remains nearly unaffected throughout extended drought period. However, the basaltic aquifers are generally delicate, easily exhausted due to manmade actions and over use of groundwater [3]. With the growing populaces distributed over a large geographical area, the demands of groundwater increased in command area [3] [4].

In industry and agriculture activities, there has been increasing concern about the quantity and quality of groundwater resources [5]. For sustainable management and safeguard of precious groundwater resources, the categorization and understanding of the environmental evolution of subsurface geochemistry are crucial to explain their element nature and its relation [6]. Presently, the hydrogeochemistry study of subsurface water in this area has not been examined in depth on a basin-wide scale and poorly unwritten. The aim of this paper is to portray the groundwater class in the Ghod river basin in multi-layered aquifer using geochemical analysis.

\section{Material and Methodology}

\subsection{Study Area}

The River Ghod originates in the Bhimashankar area at approx. $1090 \mathrm{~m}$ above sea level. It is a tributary of the River Bhima that flows in an east-southeast direction for approximately $200 \mathrm{~km}$ before its confluence with the River Bhima. It flows from the northern side of the Bhimashankar hills. The Ghod River itself has two tributaries-River Meena and River Kukadi. There is a long canal constructed along the Ghod river bank. The Dimbhe dam is located in the Ghod basin and is part of the Kukadi project. Figure 1 is location map of the study area. The right side of figure shows the India showing Maharashtra state having Pune district and study area.

The Dimbhe reservoir is designed to irrigate hectares of land and generate 5 MW power through a powerhouse built at the downstream of the dam. The study area experiences good to high rainfall during the southwest monsoon (June-August) and northeast monsoon (October-December) seasons. The measured rainfall varies from 650 to $900 \mathrm{~mm} /$ day. The temperature of the area varies from $20^{\circ} \mathrm{C}$ to $34^{\circ} \mathrm{C}$ and the maximum in the summer seasons.

The study area is occupied by the horizontal flows of basalt, showing Ajanta, Karla, Lower Ratangarh and Upper Ratangarh Formation (Figure 1).

\subsection{Sampling and Analytical Procedures}

The total of 46 groundwater samples was collected from shallow $(<10.0 \mathrm{~m}$ depth), and deep aquifer (>10.0 m depth). The systematic sampling method was 




Figure 1. Location map of study area showing sampling location.

chosen in order to indicate the groundwater quality in the study region (Figure 1). The subsurface samples were collected in prewashed sampling bottle. The physicochemical parameter measured in the field immediately after were $\mathrm{pH}$, temperature, electrical conductivity (EC), and total dissolved solids (TDS) using the handheld meter and data-logging. All samples brought to the laboratory and stored at $4^{\circ} \mathrm{C}$. The samples were collected in 1 Liter and $100 \mathrm{ml}$ sampling bottles. The $100 \mathrm{ml}$ sample is acidified with nitric acid $\left(\mathrm{HNO}_{3}\right)$ to maintain a $\mathrm{pH}$ of less than 2 to reduce adsorption of metals to container walls and decreases biological activity. Future the samples were filtered through $0.45 \mu \mathrm{m}$ membrane filter to remove unwanted suspended particle. All the groundwater collection method and the water sample analysis followed standard procedure [7].

The $\mathrm{Ca}, \mathrm{Mg}, \mathrm{HCO}_{3}$ and $\mathrm{Cl}^{-}$were analysed by titrimetric methods [7]. The $\mathrm{Na}$ and $\mathrm{K}$ concentrations were determined by flame photometric method while $\mathrm{SO}_{4}^{2-}, \mathrm{PO}_{4}^{3-}$, and $\mathrm{NO}_{3}^{-}$were analyzed by using UV-VIS spectrophotometer. The Fe and Mn usingwere determined by a nano-colorimeter (500D). All concentrations are expressed in milligrams per liter $(\mathrm{mg} / \mathrm{L})$, except for $\mathrm{pH}$ and EC. Analytical precision of the major ionic constituents was measured by the normalized inorganic charge balance. The charge balance errors in all groundwater samples are within $\pm 5 \%$, which is considered to be acceptable [8]. Aquachem software was used for the analysis. 


\section{Result and Discussion}

\subsection{Hydrogeochemical Facies}

Hydrogeochemical diagrams are aimed at facilitating interpretation of evolutionary trends, particularly in groundwater system, when they are interpreted in conjunction with distribution maps and hydrochemical sections [9]. The Piper diagram in Figure 2(a) shows the prominent groundwater facies of the shallow aquifer is $\mathrm{Ca}-\mathrm{HCO}_{3}$ and $\mathrm{Na}-\mathrm{HCO}_{3}$ indicating fresh and mix-water types respectively. In deep groundwater aquifer (Figure 2(b)), $\mathrm{Na}-\mathrm{HCO}_{3}$ type water is dominant. $\mathrm{Ca}-\mathrm{HCO}_{3}$ facies indicate that the groundwater samples are associated with calcite solution. The majority of groundwater resources were $\mathrm{Ca}+\mathrm{Mg}-$ $\mathrm{HCO}_{3}+\mathrm{CO}_{3}$ dominant as the dissolution of primary silicates due to process of chemical weathering [10]. Despite this, the water from $\mathrm{Ca}-\mathrm{Mg}$ rich basaltic flows, the surface water is always deprived with $\mathrm{Ca}$ and $\mathrm{Mg}$ because of setting of those ions in their carbonates as the result of alkaline nature of water. Also, majority of the wells occupies the inner diamond area as rock dominance prevalence. Dug wells or shallow groundwater are evenly embedded in diamond area, while bore wells or deep groundwater bowing towards $\mathrm{Ca}+\mathrm{Mg}-\mathrm{HCO}_{3}+\mathrm{CO}_{3}$ due to long residence time available for rock-water interactions [11].

It is observed that changing of $\mathrm{Ca}+\mathrm{Mg}-\mathrm{HCO}_{3}+\mathrm{CO}_{3}$ to $\mathrm{Na}+\mathrm{K}-\mathrm{SO}_{4}+\mathrm{Cl}$ is more in bore well or deep aquifer than dug well or shallow aquifer [12]. This is due to greater depth of bore well wherein high residence time groundwater exists due to the increased rock-water interaction. However, surface water is having high evaporation that results into feeble displacement in $\mathrm{Ca}+\mathrm{Mg}-\mathrm{HCO}_{3}+$ $\mathrm{CO}_{3}$ to $\mathrm{Na}+\mathrm{K}-\mathrm{SO}_{4}+\mathrm{Cl}$ water facies due to less rock-water interaction [12].

\subsection{Sodium Adsorption Ratio (SAR)}

The groundwater quality from shallow and deep aquifer were classified and compared with sodium absorption ratio (SAR). The SAR calculate the ions of sodium $\left(\mathrm{Na}^{+}\right)$to calcium $\left(\mathrm{Ca}^{2+}\right)$ and magnesium $\left(\mathrm{Mg}^{2+}\right)$ ratio in groundwater samples. Sodium hazard of irrigation water is important in classifying the water for agriculture purposes because sodium concentration can reduce the soil permeability and soil structure [13] and calculated by using Equation (1) [14]

$$
S A R=\frac{\mathrm{Na}^{+}}{\left\{\frac{\mathrm{Ca}^{2+}+\mathrm{Mg}^{2+}}{2}\right\}^{0.5}}
$$

The USSL graphical diagrams of irrigation water plotted the SAR and electrical conductivity (Figure 3). Based on USSL diagram [15], groundwater samples from shallow aquifer fall in the C1-S1 (low salinity with lowsodium), C2-S1 (medium salinity with low sodium) and C3-S1 (high salinity with sodium). Hence, the groundwater from shallow aquifer can be used on most crops for irrigation purposes. For the deep aquifer, samples fall in the medium salinity and low alkalinity region C2-S1. Only one of the samples falls in the region C3-S1, which indicates high salinity with low alkalinity. Generally, the study area indi- 


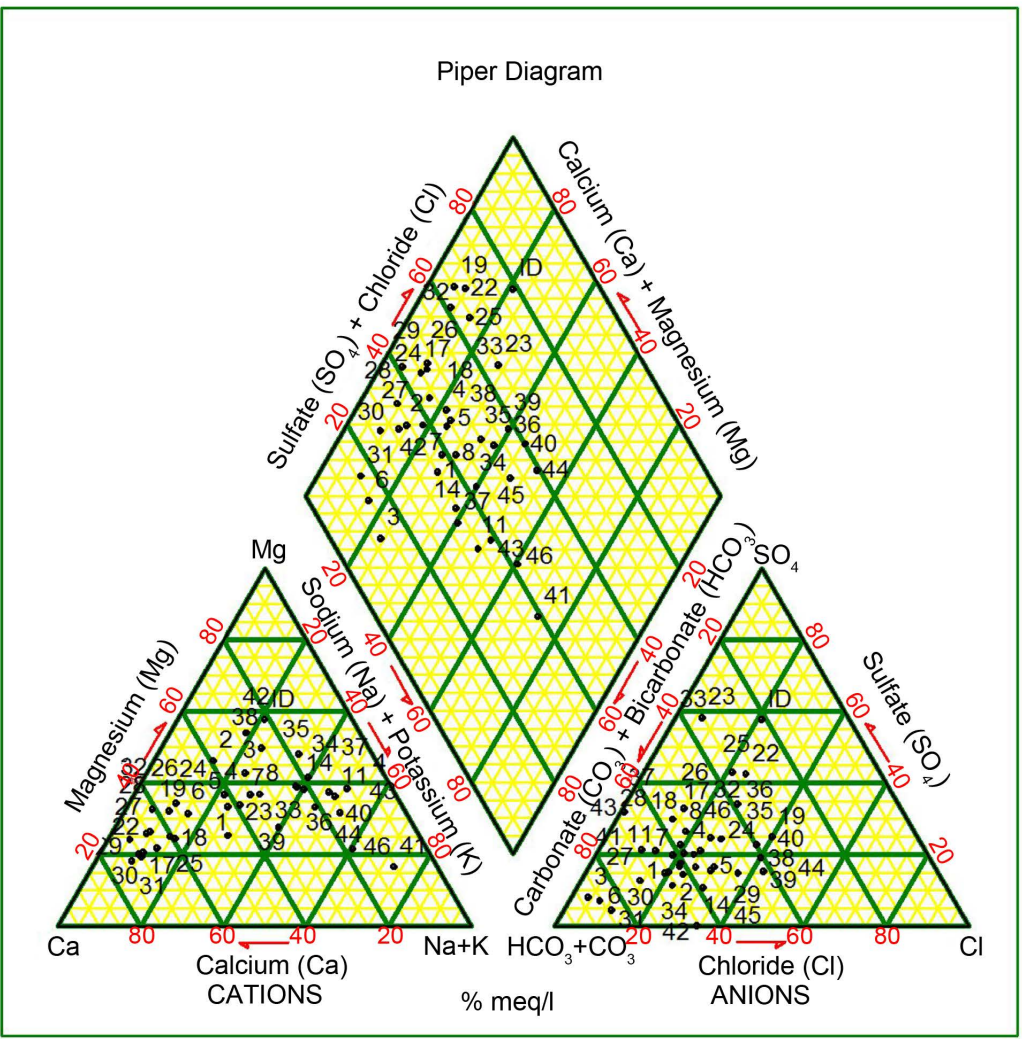

(a)



(b)

Figure 2. Piper diagram in (a) shallow groundwater,(b) deep groundwater. 


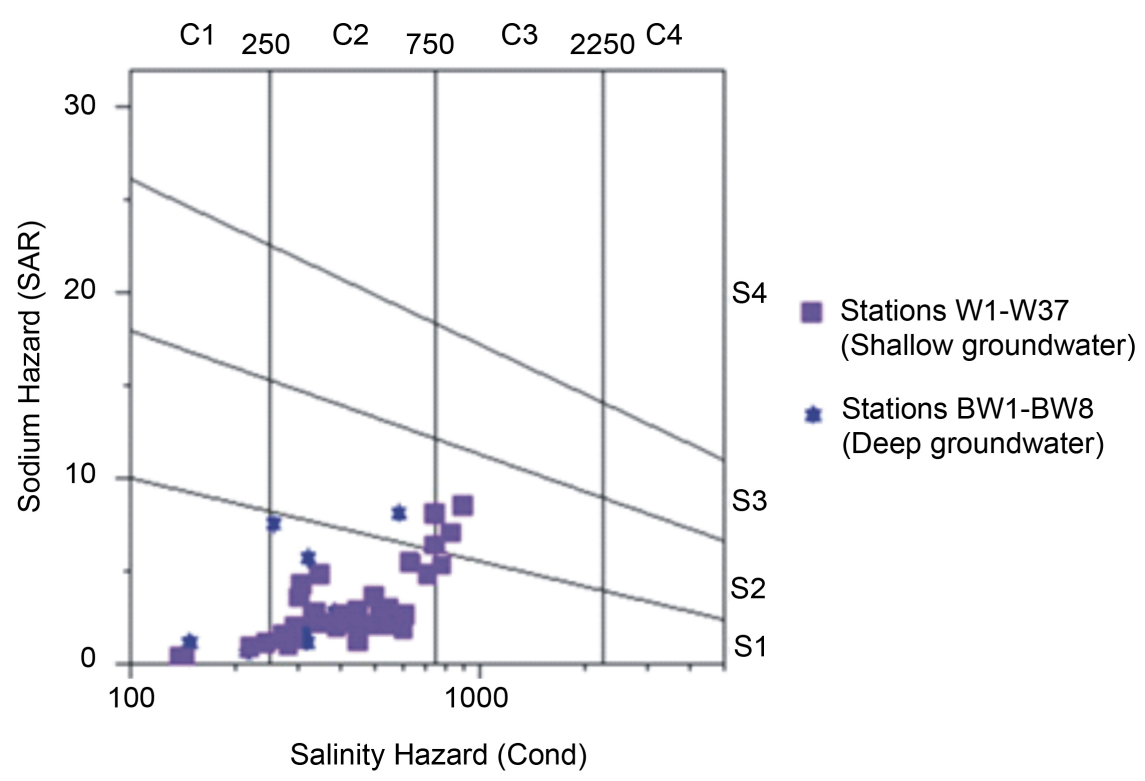

Figure 3. USSL graphical diagrams of shallow groundwater and deep groundwater.

cates low to high salinity and low to medium alkalinity water, which can be used for irrigation in almost all types of soils with a little danger of exchangeable sodium.

\section{Conclusion}

Results of the analysis show that the shallow groundwater type is dominated by $\mathrm{Ca}-\mathrm{HCO}_{3}$ and $\mathrm{Na}-\mathrm{HCO}_{3}$ and deep groundwater $\mathrm{Na}-\mathrm{HCO}_{3}$ as basaltic groundwater. The $\mathrm{Na}-\mathrm{HCO}_{3}$ facies could be due to albite solution of weathered Gyroliteand Siderophyllite of the study area. The bicarbonates are mainly derived from carbonate mineral and silicate weathering. However, salinity in study area is to be added with increase in annual rainfall which offers sufficient aqueous medium for rock/soil-water interaction under in semi-arid climatic regime. The process of rock dominance is dominant followed by precipitation and evaporation. Finally, the groundwater of the Ghod river Basin is suitable for drinking, domestic and agriculture irrigation use. The people from study area will have adopted sustainable water use plan for surface and subsurface water to monitor and control groundwater quality for anodyne usage of the resource.

\section{Acknowledgements}

The authors are thankful to Principal, N. Wadia College Pune, India for extending help to use the department laboratory for computing facilities.

\section{References}

[1] United Nations Environment Program (UNEP) (1999) Global Environment Outlook 2000. Earthscan, UK.

[2] Giridharan, L., Venugopal, T. and Jayaprakash, M. (2008) Evaluation of the Seasonal Variation on the Geochemical Parameters and Quality Assessment of the 
Groundwater in the Proximity of River Cooum, Chennai, India. Environmental Monitoring and Assessment, 143, 161-178. https://doi.org/10.1007/s10661-007-9965-y

[3] Ismail, T. and Anuar, S. (2010) Potential of Groundwater Contamination in North Kelantan. Proceedings of Seminar Geofizik Kejuruteraandan Sekitaran, 6 Januari 2010, Program Geologi, PPSSSA, FST, UKM 2010, 155-163.

[4] Kadam, A.K., Kale, S.S., Pande, N.N., et al. (2012) Identifying Potential Rainwater Harvesting Sites of a Semi-Arid, Basaltic Region of Western India, Using SCS-CN Method. Water Resources Management, 26, 2537-2554. https://doi.org/10.1007/s11269-012-0031-3

[5] Alvarado, A., Esteller, M.V., Quentin, E. and Expósito, J.L. (2016) Multi-Criteria Decision Analysis and GIS Approach for Prioritization of Drinking Water Utilities Protection Based on Their Vulnerability to Contamination. Water Resources Management, 30, 1549-1566. https://doi.org/10.1007/s11269-016-1239-4

[6] Arauzo, M. and Martínez-Bastida, J.J. (2015) Environmental Factors Affecting Diffuse Nitrate Pollution in the Major Aquifers of Central Spain: Groundwater Vulnerability vs. Groundwater Pollution. Environmental Earth Sciences, 1-16.

[7] APHA (2005) Standard Methods for the Examination of Water and Wastewater. 20th Edition, American Public Health Association, Washington DC.

[8] Hem, J.D. (1989) Study and Interpretation of the Chemical Characteristics of Natural Water. 3rd Edition, United States Geological Survey, Washington DC.

[9] Piper, A.M. (1944) A Graphical Interpretation of Water Analysis. TransactionsAmerican Geophysical Union, 25, 914-928.

https://doi.org/10.1029/TR025i006p00914

[10] Pawar, N.J., Thigale, S.S. and Powar, K.B. (1982) Chemistry of Groundwaters from Pune Area, Maharashtra. Proceedings of International Symposium on Hydrological Aspects of Mountainous Watersheds, Roorkee, Vol. I, X1-X6.

[11] Pawar, N.J., Pawar, J.B., Suyash, K. and Ashwini, S. (2008) Geochemical Eccentricity of Ground Water Allied to Weathering of Basalt from the Deccan Volcanic Province, India: Insinuation on $\mathrm{CO}_{2}$ Consumption. Aquatic Geochemistry, 14, 41-71. https://doi.org/10.1007/s10498-007-9025-9

[12] Rajmohan, N. and Elango, L. (2005) Distribution of Iron, Manganese, Zinc and Atrazine in Groundwater in Parts of Palar and Cheyyar River Basins, South India. Environmental Monitoring and Assessment, 107, 115-131. https://doi.org/10.1007/s10661-005-5307-0

[13] Todd, D.K. (1980) Groundwater Hydrology. 2nd Edition, John Wiley and Sons, New York, 535.

[14] Richards, L.A. (1954) Diagnosis and Improvement of Saline and Alkaline Soils Agriculture Handbook. Department of Agricultural, Washington DC, 160.

[15] USSL (1954) Diagnosis and Improvement of Salinity and Alkaline Soil. USDA Hand Book No. 60, Washington DC. 
Submit or recommend next manuscript to SCIRP and we will provide best service for you:

Accepting pre-submission inquiries through Email, Facebook, LinkedIn, Twitter, etc. A wide selection of journals (inclusive of 9 subjects, more than 200 journals)

Providing 24-hour high-quality service

User-friendly online submission system

Fair and swift peer-review system

Efficient typesetting and proofreading procedure

Display of the result of downloads and visits, as well as the number of cited articles Maximum dissemination of your research work

Submit your manuscript at: http://papersubmission.scirp.org/

Or contact jwarp@scirp.org 